\title{
NEGRO, CRIANCAA, CABELO DE MOLA: AQUI VOCÊ NÃO ENTRA!(?)
}

\author{
BLACK, CHILD, SPRING HAIR: \\ HERE YOU ARE NOT WELCOME!(?)
}

\author{
Érika de Sousa Mendonça1 \\ [https://orcid.org/0000-0003-0031-3608] \\ Suely Emilia de Barros Santos ${ }^{2}$ \\ [https://orcid.org/0000-0001-6249-7487] \\ Tarcia Regina Silva ${ }^{3}$ \\ [https://orcid.org/0000-0002-4392-3468] \\ DOI: 10.30612/raido.v15i37.14641
}

RESUMO: Refletir sobre relaçōes étnico-raciais, considerando implicaçōes históricas e políticas entre negros e brancos na construçâo de uma ideologia racial que persiste, é tarefa necessária quando situaçôes de racismo săo protagonizados e sofridos diariamente, desde a infância. $\mathrm{O}$ artigo se propóe, sob esta lente, a analisar uma obra da literatura infantil intitulada "Cabelo de Mola", discutindo o preconceito racial a partir do seu mote principal: a exclusăo de uma criança negra por crianças brancas com base somente na cor de pele. Sob a perspectiva teórico-metodológica das práticas discursivas, da produçấo de sentidos no cotidiano e à luz dos debates sobre branquitude, refletiu-se sobre trechos narrativos retirados do livro citado, elegendose duas categorias de discussâo: i) "Todos olharam feio e desprezaram Eduardo por ele ser negro", em que se refletem efeitos da branquitude desde a infância, na construçâo de sujeitos sociais; e ii) "Tentou novamente se aproximar, dessa vez com bolinhas de gude", tópico em que se discute o sujeito negro e os movimentos de barganha que se lhe impóem para adentrar o universo branco. Por fim, evidenciamos que a literatura analisada contribui mais para o reforço do privilégio branco do que para um caminhar na trilha da desconstruçầo de desigualdades raciais.

1 Doutora em Psicologia pela Universidade Federal de Pernambuco (UFPE). Professora adjunta do curso de graduação em Psicologia da Universidade de Pernambuco (UPE). Pesquisadora do Mestrado Profissional em Culturas Africanas, da Diáspora e dos Povos Indígenas da UPE. E-mail erika.mendonca@upe.br

2 Doutora em Psicologia Clínica (UNICAP). Professora adjunta do curso de Psicologia da Universidade de Pernambuco (UPE). Pesquisadora dos Programas de Pós-Graduaçăo em Psicologia, Práticas e Inovaçâo em Saúde Mental (PRISMAL), e Saúde e Desenvolvimento Socioambiental (PPGSDS). Coordena o grupo de pesquisa LACS/UPE/CNPq. E-mail: suely.emilia@upe.br

3 Doutora em Educaçăo pela Universidade Federal da Paraíba (UFPB). Professora adjunta da Universidade de Pernambuco (UPE). Pesquisadora do Programa de Pós-graduaçâo em Culturas Africanas, da Diáspora e dos Povos Indígenas (PROCADI) e Saúde e Desenvolvimento Socioambiental (PPGSDS). Coordenadora de Desenvolvimento de Graduaçâo da Universidade de Pernambuco. E-mail: tarcia.silva@upe.br 
Palavras-chave: Literatura infantil; Relaçōes étnico-raciais; Branquitude; Racismo; Infância.

ABSTRACT: To reflect on ethnic-racial relations is a necessary task, considering the historical and political implications between blacks and whites in the construction of a racial ideology and taking into account the daily situations of racism in Brazil since childhood. This article proposes to analyze a work of children's literature titled "Cabelo de Mola" discussing the exclusion of a black child by white children, based solely on skin color. Under the theoretical and methodological perspective of discursive practices and the production of meanings in everyday life, and the debates on whiteness, narrative excerpts taken from the book were reflected, choosing two categories of discussion: i) "Everyone looked ugly and despised Eduardo because he is black", which the effects of whiteness are reflected since childhood, in the construction of social subjects; and ii) "He tried again to approach, this time with marbles", a topic which discuss the black subject and the bargaining movements that are imposed to enter the white universe. Finally, we show that the analyzed literature contributes to the reinforcement of the white privilege, and does not favor a deconstruction of racial inequalities.

Keywords: Children's literature; Ethno-racial relations; Whiteness; Raciality; Racism; Childhood.

\section{INTRODUÇÃO}

Para o estudo aqui desenvolvido, partimos do princípio de que é preciso estabelecer novas relaçóes étnico-raciais em nossa sociedade, o que implica a reeducaçâo das relaçóes entre negros e brancos (BRASIL, 2004). Nesse sentido, reconhecemos que o branqueamento, uma das facetas da branquitude, foi considerado, ao longo da história do nosso país, um problema da populaçăo negra que, năo satisfeita com a sua cor, "procura identificar-se como branco, miscigenar-se com ele para diluir suas características" (BENTO, 2014, p. 25).

Entretanto, é necessário destacar que o sujeito branco pouco é evidenciado no referido debate. Nesta tessitura, Bento (2014) notabiliza que o branqueamento é uma noçấo inventada e sustentada pela elite brasileira branca, pois esta tinha receio da expressiva populaçăo negra aqui presente no início do processo de colonizaçáo. Mais tarde, esse conceito também serviu como um interdito à ascensáo desta populaçăo. Diante de um cenário que convida à reflexăo sobre os processos de racializaçăo socialmente construídos - estes que diferenciam sujeitos e impactam nas relaçóes cotidianas -, faz-se necessário considerar a responsabilizaçăo que envolve tanto a participaçăo de sujeitos negros quanto a participaçấo de sujeitos brancos.

Basta um olhar minimamente atento às relaçōes constituídas entre sujeitos de uma mesma raça ou, sobretudo, de raças distintas - diferenciaçôes estas baseadas na cor de pele e em características fenotípicas, como cabelos crespos e lábios grossos -, que percebemos tensionamentos ou mesmo polarizaçōes e atos de intolerância, exclusăo e racismo. Se estas percepçōes acontecem nos diversos ambientes sociais, também o lócus de sua expressāo pode ser encontrado em artefatos culturais, como em filmes, em músicas e na literatura. 
Para as reflexóes que pretendemos aqui apresentar, selecionamos uma obra de literatura infantil intitulada "Cabelo de Mola", de autoria de Alexsander Rezende, que também foi responsável pelas ilustraçôes. O livro foi lançado pela Paulus Editora em 2012. Na sinopse, lê-se: “Em Cabelo de Mola, a história é protagonizada por Eduardo, um garoto negro, vítima de preconceito e que precisa enfrentar as provocaçóes em relaçăo a sua cor para impor respeito e admiraçăo no novo bairro em que mora"4 . Tais provocaçôes a que se refere a sinopse se dăo entre o menino negro, Eduardo, e outras crianças, todas elas brancas e com condutas excludentes. Trata-se de um livro curto, imagético, contendo 24 (vinte e quatro) páginas, cujo conteúdo, embora sintético, se revela complexo nos debates que provoca e tem como público-alvo crianças pequenas, entre 4 (quatro) e 5 (cinco) anos de idade.

Sobre os trechos narrativos deste livro, recorremos a um olhar guiado pelas práticas discursivas e pela produçâo de sentidos no cotidiano como abordagem teórico-metodológica de análise, uma vez que compreendemos a literatura como prática discursiva que contribui para a produçâo/reproduçâo de sentidos e para o fortalecimento de estereótipos, da branquitude e da inclusăo/exclusăo de sujeitos negros. Tal abordagem busca problematizar o contexto discursivo sem perder de vista a interaçăo. No caso do presente estudo, tem-se tanto a interaçáo entre personagens quanto a interaçáo da produçăo literária com o cenário nacional em que se insere. Assim, buscamos direcionar atençấo aos sentidos que se produzem a partir disso, especificamente sobre as relaçōes sociais entrecortadas pelo critério racial.

Spink (2010) nos apresenta a produçáo de sentidos como um fenômeno sociolinguístico, como uma construçấo social coletiva e interativa que está na base da Psicologia Social, tanto em sua vertente sociocognitiva, quanto na vertente interacional.

O sentido é uma construçăo social, um empreendimento coletivo, mais precisamente interativo, por meio do qual as pessoas - na dinâmica das relaçóes sociais historicamente datadas e culturalmente localizadas - constroem os termos a partir dos quais compreendem e lidam com as situaçóes e fenômenos à sua volta. (SPINK; MEDRADO, 2013, p. 41)

Para os autores, a produçăo de sentidos está intrinsecamente relacionada às práticas discursivas, sendo estas as "maneiras a partir das quais as pessoas produzem sentidos e se posicionam em relaçōes sociais cotidianas" (SPINK; MEDRADO, 2013, p. 45). Desse modo, nas práticas discursivas e na produçăo de sentidos do cotidiano, busca-se evidenciar processos através dos quais as pessoas compreendem a si mesmas e se posicionam no mundo em que vivem, localizando regularidades, acordos, consensos, mas também a polissemia, as tensōes, as contradiçōes e os sentidos socialmente partilhados - tais como critérios qualificatórios de pessoas a partir da cor de pele.

Como ilustraçăo destes aspectos, reconhecemos, na literatura analisada, implicitamente, os posicionamentos do autor que, ao criar os personagens, as narrativas e o próprio título do livro, posiciona crianças numa relaçāo de tensionamento perpassada

4 Essa sinopse está disponível em: 〈https://www.paulus.com.br/loja/cabelo-de-mola_p_3054.html〉. Acesso em: 13 abr. 2021. 
pela racialidade. O desfecho apresentado pelo autor para a resoluçăo do impasse é, inclusive, analisado e compreendido por nós como práticas discursivas que produzem sentidos reforçadores de diferenciaçōes e preconceitos raciais.

Aqui, entendemos, enfim, que as práticas discursivas tratam da linguagem em açáo, da linguagem como prática social, o que possibilita a circulaçáo de conteúdos, gera posicionamentos, constrói sentidos e produz efeitos. Dessa forma, centramo-nos na linguagem em uso, compreendendo que palavras constroem sentidos articuladas a seu contexto de produçāo, contexto este que é político, econômico, cultural. Uma análise concebida sob as lentes das práticas discursivas busca, portanto, problematizar desde os elementos indicadores de regularidades no uso diário de discursos pelas pessoas - o que evoca reproduçôes sociais - até os momentos de ressignificaçóes, rupturas e produçôes de sentidos, quando as pessoas se posicionam nas relaçóes cotidianas, tal como refere Spink (2010). Atende, assim, a uma dupla exigência: trabalhar com a processualidade do cotidiano e entender os discursos como uma linguagem social expressa em diversos domínios de saberes e fazeres (MENDONÇA, 2008).

A partir de um olhar às questôes raciais, considerando-se a historicidade e as motivaçôes políticas que repercutem na construçăo da branquitude - que sustenta uma ideologia racial geradora de preconceitos diários -, este artigo se propôe a analisar o livro literário infantil "Cabelo de Mola" a partir do preconceito racial e da branquidade como norma pela obra evidenciada. As indagaçóes que guiam este estudo sâo as seguintes: as tentativas de desconstruçáo do racismo a que a obra se propóe sâo bem sucedidas? A abordagem do privilégio branco desde a infância e o movimento de barganha assumido pela criança negra, para se fazer pertencente ao grupo formado por outras crianças (todas brancas), contribuem para a desconstruçăo do racismo? Essa abordagem fortalece diferenciaçôes e preconceitos raciais?

\section{REFERENCIAL TEÓRICO}

Reconhecemos a literatura como um direito humano. Assim, como fator imprescindível de humanizaçăo, a literatura "confirma o homem na sua humanidade, inclusive porque atua em grande parte no subconsciente e no inconsciente" (CANDIDO, 2011, p. 175). Nessa perspectiva, concebemos como um direito de todos se sentirem representados positivamente por ela, pois "todas as pessoas em nossa cultura sâo incentivadas a ainda enxergar livros que tenham imagens de pessoas brancas como obras para e sobre todas as pessoas" (HOOKS, 2020, p. 219).

Desse modo, no contexto da reeducaçăo das relaçôes étnico-raciais, a representaçăo positiva da populaçấo negra desde a infância é relevante, considerando-se que

[o] carrasco é o homem negro, Sată é negro, fala-se de trevas, quando se é sujo, se é negro - tanto faz que isso se refira à sujeira física ou à sujeira moral. Ficaríamos surpresos se nos déssemos ao trabalho de reunir um grande número de expressóes que fazem do negro o pecado. Na Europa, o preto, seja concreta, seja simbolicamente, representa o lado ruim da personalidade. Enquanto náo compreendermos esta proposiçáo, estaremos condenados a falar em vâo do 'problema negro'. O negro, o obscuro, a sombra, as trevas, a noite, os labirintos da terra, as profundezas abissais, enegrecer a reputaçấo de alguém; e, do outro lado: o olhar claro da inocência, a 
pomba branca da paz, a luz feérica, paradisíaca. Uma magnífica criança loura, quanta paz nessa expressăo, quanta alegria e, principalmente, quanta esperança! Nada de comparável com uma magnífica criança negra, algo absolutamente insólito. (FANON, 2008, p. 160)

Esse cruel olhar refletido sobre a populaçăo negra influencia, até os dias atuais, a construçáo da identidade da criança negra. Ao balizar o seu grupo como exemplo de toda a humanidade, a elite branca - num posicionamento denominado branquitude - fez uma tomada simbólica que tem consolidado a "autoestima e o autoconceito do grupo branco em detrimento dos demais, e essa apropriaçăo acaba legitimando sua supremacia econômica, política e social" (BENTO, 2014, p. 25). Na outra ponta desta história, está a populaçăo negra, que, a partir dessa situaçăo, cotidianamente luta em favor da construçâo positiva da sua identidade racial, buscando romper com a sua imagem atrelada ao imaginário negativo eurocêntrico que corrói a sua autoestima.

Para Bento (2014), ao evidenciarmos a discussáo racial apenas pelo lado do negro, legitimamos que as desigualdades raciais existem como um infortúnio específico do negro, já que somente ele é estudado, problematizado. Dessa maneira, devemos nos debruçar também sobre o papel dos brancos na produçáo dessas desigualdades, pois é necessário avultar as variadas interfaces desse privilégio de ser branco, especialmente porque, por mais pobre que seja uma pessoa branca, ela ainda goza de um privilégio por sê-lo. Essa, pois, é uma populaçăo que, após a escravidăo, se beneficiou de uma herança simbólica e material bastante positiva, e a năo visibilizaçăo deste legado permite a manutençâo do cenário em voga.

Em face disso, propomo-nos, neste artigo, a analisar os efeitos da branquitude como norma e suas repercussóes desde a infância, através da análise do livro de literatura infantil "Cabelo de Mola", de autoria de Alexsander Rezende. Esse livro apresenta a narrativa de uma criança chamada Eduardo, "um menino que adora todas as brincadeiras, mas a sua favorita é futebol" (REZENDE, 2012, p. 4). Eduardo e sua família se mudaram para um novo bairro, e ele estava muito ansioso para conhecer os novos vizinhos/colegas. Entretanto, um dia após a sua mudança, "aconteceu algo lamentável! Todos olharam feio e desprezaram Eduardo por ele ser negro" (REZENDE, 2012, p. 6). Mas qual o problema de ser um menino negro? Por que a cor de Eduardo, um menino negro, faz com que ele seja rejeitado pelos novos vizinhos, meninos e brancos?

Esta narrativa nos faz atentar para o que apontou Fanon (2008, p. 109): "minha negrura era densa e indiscutível. Ela me atormentava, me perseguia, me perturbava, me exasperava". A cor tirava de Eduardo, e vem tirando de muitas crianças negras, o direito de ser aceito, acolhido, amado e respeitado. É a cor negra, ainda, que tem se constituído como um interdito à populaçăo negra desde a infância. Assim, o universo branco, as crianças brancas estavam negando a Eduardo sua participaçáo social. Nesse cenário, exigia-se dele uma conduta diferente da que se exige de qualquer menino, por meio da "conduta de homem negro - ou, pelo menos, uma conduta de preto. Eu acenava para o mundo e o mundo amputava meu entusiasmo. Exigiam que eu me confinasse, que encolhesse" (FANON, 2008, p. 107).

Refletindo sobre tal arranjo, Bento (2014) destaca que ter a si como referência e projetar as mazelas que náo se assume para os outros sáo processos naturais associados 
ao narcisismo e à projeçăo. A constituiçăo do năo europeu em sujeito estranho construiu o negro como uma ameaça. Essa construçâo é fortemente permeada pela presença do componente narcísico, ou seja, aversăo a tudo que é estranho, que é diferente. O amor do branco por si mesmo é fortalecido por uma base que engendra esse grupo como referência. O diferente, Eduardo, menino negro, quando se faz presente, tensiona o universal, desestabiliza a brincadeira, aquele universo composto só por meninos brancos, gerando aversâo e antipatia.

No contexto das relaçôes étnico-raciais, a escolha de um livro de literatura infantil que traz uma narrativa preconceituosa que năo favorece a identidade da criança negra ostenta uma aparência mais densa, pois autentica a conjuntura de superioridade dos brancos sobre os negros desde a mais tenra idade. Logo, optar por uma narrativa assim legitima "as desigualdades, a apropriaçấo indébita de bens concretos e simbólicos, e a manutençâo de privilégios" (BENTO, 2014, p. 31). Diante disso, compreender a branquitude e o processo de branqueamento é entender a projeçấo do branco sobre o negro, que é nascida do medo, cercada de silêncio, fiel guardiă dos privilégios (BENTO, 2014). O que se vê comprometida, nesse processo, é a própria capacidade de identificaçăo com o próximo, criando-se, desse modo, as bases de uma intolerância generalizada contra tudo que possa representar a diferença.

Cardoso (2010a) destaca que os brancos săo diversos e que a branquidade pode se constituir como crítica e acrítica. A primeira desaprova publicamente o racismo, enquanto a segunda enfatiza que ser branco é uma condiçâo especial, um privilégio. Piza e Rosemberg (2014) diferenciam os termos "branquitude" e "branquidade", fazendonos atentar para o fato de que a percepçâo da populaçăo branca sobre a questấo racial náo pode ser universalizada. As autoras salientam que,

[...] ainda que necessite amadurecer em muito esta proposta, sugere-se aqui que a branquitude seja pensada como uma identidade branca negativa, ou seja, um movimento de negaçấo da supremacia branca enquanto expressâo de humanidade. Em oposiçăo à branquidade (termo que está ligado também à negridade, no que se refere aos negros), branquitude é um movimento de reflexăo a partir e para fora de nossa própria experiência enquanto brancos. É o questionamento consciente do preconceito e da discriminaçấo que pode levar a uma açăo política antirracista. A autora reconhece a branquidade como um produto da história, ou seja, enquanto o negro é visto como o representativo de um todo, um branco é visto na sua individualidade. Logo, um branco é uma representativa apenas de si mesmo. (PIZA; ROSEMBERG, 2014, p. 72)

Os brancos năo sâo, em sua totalidade, perigosos ou malandros: isso é relativizado, uma vez que é possível que algum deles seja - este seria uma exceçấo. Entretanto, quando se pensa nesse aspecto em relaçăo à populaçăo negra, pensa-se nela como um todo, generalizando-a. Nesse sentido, as autoras supracitadas salientam que o que está em destaque náo é a invisibilidade da cor, mas a supervalorizaçâo da cor e de outros traços do fenótipo, que estāo associados a estereótipos sociais e morais para uns, em contraste com a neutralidade racial para os outros.

Arroyo (2012, p. 185) também apresenta a ideia de que a centralidade do nosso processo de colonizaçăo residiu no fato de "classificar as 'raças de cor' como inferiores" por natureza. Esse seria um mito metafísico que ainda perdura. De acordo com o autor, 
a populaçăo negra, pensada a partir do processo de colonizaçăo, năo foi tornada inferior, mas considerada inferior por natureza. Logo, ela foi concebida como náo humana. Assim, năo há como reconhecê-la "na história humana, cultural, intelectual, civilizatória e educativa" (ARROYO, 2012, p. 186). O autor sinaliza, ainda, que a desconstruçăo do caráter histórico do mito colonizador impacta na desconstruçăo do caráter metafísico das pessoas negras. Entăo, contar a sua história, estar presente positivamente nas histórias, territorializar o campo da história, da literatura é existir. No entanto, precisamos atentar para como essa história está sendo contada e para como a populaçáo negra está sendo representada.

Mesmo após a Lei 10.639/2003 (BRASIL, 2003), atual Lei 11.645/2008 (BRASIL, 2008), que promoveu um fomento de obras de literatura infantil com a temática das relaçōes étnico-raciais, é importante ponderar as práticas discursivas presentes nessas narrativas, pois a literatura, segundo Candido (2011, p. 175), "confirma e nega, propóe e denuncia, apoia e combate, fornecendo a possibilidade de vivermos dialeticamente os problemas". Para o autor, a literatura possibilita a organizaçăo de nossos pensamentos e sentimentos, e, como consequência disso, tornamo-nos mais qualificados para organizar a nossa visăo de mundo.

Nesse cenário, Santos (2015) tem destacado a importância de as crianças - neste caso, meninos negros - terem contato com estratégias pedagógicas, bem como com livros de literatura infantil, que possibilitem a reflexăo sobre o privilégio branco, que os ajudem a reeducar as relaçóes étnico-raciais. É preciso que isso favoreça os primeiros momentos das crianças na escola, de forma que elas possam ter a oportunidade de compreender as diferenças e como essas diferenças estăo sendo transformadas em desigualdades, visto que, segundo Hooks (2020, p. 219), "as representaçóes dos meninos negros, com frequência, limitam e confinam seu corpo e sua personalidade".

Para evidenciar a questáo da branquitude como norma desde a infância, Souza (2009) problematizou, através de bonecos e bonecas com corpos diferentes - negro(a), de óculos, gordo(a), de cabelo liso, crespo, carapinha -, os conceitos de corpo, raça e gênero das crianças pequenas nas suas brincadeiras. Ao interagirem com os(as) bonecos(as) negros(as), ou quase negros(as) (como descreve a pesquisadora, por tentarem se assemelhar à populaçấo negra na cor, mas permanecerem com o fenótipo da populaçáo branca), as crianças produziram um discurso atravessado por marcadores de feiuras. Essas marcas foram associadas à cor da pele e ao tipo de cabelo.

Candido (2011, p. 175) enfatiza que cada sociedade, ao criar as suas narrativas ficcionais, poéticas e/ou dramáticas, o faz em conformidade com "os seus impulsos, as suas crenças, as suas normas, a fim de estabelecer em cada um a presença e a atuaçáo deles". Na análise que se propóe no presente artigo, percebemos que, ao nomear a obra por "Cabelo de Mola", o autor nos leva a refletir sobre o quanto nós, que estamos envoltos no campo da educaçăo, com nossas práticas discursivas, mantemos e perpetuamos o racismo internalizado.

À vista disso, os efeitos da colonialidade nos fazem cair em armadilhas que nos levam para o caminho oposto às práticas antirracistas, mesmo quando as almejamos. A análise do livro "Cabelo de Mola" nos faz ainda observar, em consonância com Candido (2011, p. 176), que a literatura năo é uma experiência isenta e inofensiva, e pode provocar danos psíquicos e morais como espelho do próprio cotidiano, pois ela tem um 
papel na formaçấo da personalidade, mas năo conforme as convençôes: "seria antes a segunda força indiscriminada e poderosa da própria realidade".

Analisando os efeitos da branquidade na infância, Trinidad (2011), em uma pesquisa com crianças entre 4 (quatro) e 5 (cinco) anos de idade, com o objetivo de verificar como elas percebem suas identificaçōes étnico-raciais, observou que, entre as crianças que se autodenominam brancas, nenhuma delas desejava ter traços físicos diferentes dos que já possuíam. Na verdade, elas desejavam ter esses traços ainda mais brancos. A autora relata que, entre as crianças brancas, o desejo de mudar a aparência só foi explicitado quando suas características se aproximavam dos traços tipicamente negros. Trinidade (2011) constatou, assim, que as crianças, mesmo as brancas, almejam um ideal maior de brancura, negando o que é do fenótipo de outro grupo étnico-racial, no caso dos negros. É essa a explicaçâo que a pesquisadora apresenta para a autodenominaçăo de uma das crianças como "branco escuro".

Além disso, a autora destaca que, no grupo das crianças negras, apresentaram-se dados nâo questionáveis acerca do descontentamento em relaçăo ao corpo e a certa negaçâo das características negras. Dessa maneira, a pesquisa reforça que, desde muito pequenas, as crianças negras năo se identificam com algumas de suas características, indicando uma desvalorizaçăo do seu pertencimento étnico-racial.

As crianças participantes deste estudo vivem em uma sociedade na qual ser negro significa portar características pessoais que săo, em relaçăo às dos brancos, consideradas 'piores'. Essa situaçăo de iniquidade é apreendida pelas crianças pretas e pardas de várias maneiras, significando, como se viu, ora ser alvo de hostilidade, ora de caçoada, ora de rejeiçăo, de modo que ser negro acaba sendo equiparado, pela grande maioria, a uma condiçăo sofrida, que deve ser transformada. (TRINIDAD, 2011, p. 169)

Conforme Amaral (2013), as crianças brancas ocupam, comumente, lugar de destaque nas brincadeiras. Em uma das suas pesquisas, também com crianças pequenas, a autora citada indica que, em todas as salas visitadas de uma escola de Educaçâo Infantil, em Curitiba, as primeiras crianças que buscavam interaçáo com ela eram as brancas. Com base em tal percepçăo, Amaral (2013) indaga se a criança branca aprende desde bebê que seus gestos, sorrisos, abraços, beijos e falas săo mais aceitos; se os brancos de cabelos loiros e olhos azuis sâo mais autoconfiantes; e se essas crianças possuem uma autoestima mais elevada. A pesquisadora destaca, ainda, que, nas atividades observadas, em geral, as crianças negras năo săo elogiadas - em contraposiçấo às brancas -, vivenciam experiências de negaçâo de afeto, de colo e de interaçăo corporal e sofrem maior repressâo de suas açôes. Nesse texto, questionamo-nos: como a literatura infantil pode colaborar e/ou se opor a essa dura realidade?

De acordo com Hooks (2004), as imagens, os símbolos, os produtos, as criaçôes, as propagandas criadas e divulgadas pela América branca, de uma maneira explícita ou implícita, ensinam os meninos negros, desproporcionalmente numerosos entre os pobres, a supremacia branca. Dessa maneira, ensinam-lhes, já na infância, a năo gostarem de si. Para a autora, temos ensinado aos meninos negros que a força, a disposiçăo física e a energia sáo os elementos que verdadeiramente importam nas suas vidas, o que, no contexto do livro "Cabelo de Mola", apresenta-se mediante a habilidade de Eduardo para o futebol. Essa forma de socializaçăo está presente desde a escravidăo até os dias atuais. 
Hooks (2004) salienta, também, que os meninos negros têm sido ainda alvo de uma educaçăo racista, e muitos nâo resistem a essa forma de socializaçăo. Segundo ela, náo é uma realidade acidental que meninos negros muito inteligentes acabem encarcerados de forma real ou subjetiva, por serem vistos como ameaçadores, maus, violentos e perigosos. Contudo, a autora considera que năo tem sido uma tarefa simples a criaçáo de imagens que representem as populaçôes negras como elas săo e como querem ser; representaçôes potentes que se oponham aos estereótipos negativos, colonizadores.

Apesar dessa dificuldade, os bebês, as crianças bem pequenas e crianças pequenas, meninos negros e meninas negras precisam ter a oportunidade de se ver representados positivamente, ampliando a fruiçâo da literatura como bem humanizador (CANDIDO, 2011). Poderăo, dessa forma, pensar em si, no outro e no mundo a partir do reconhecimento e da valorizaçăo das diferenças e da sua identidade de criança e negra.

\section{DISCUSSÃO DOS DADOS}

Das análises das práticas discursivas contidas em "Cabelo de Mola", foram eleitos dois tópicos de discussáo: i) "Todos olharam feio e desprezaram Eduardo por ele ser negro", em que se refletem os efeitos da branquitude, desde a infância, na construçâo de sujeitos sociais; e ii) "Tentou novamente se aproximar, dessa vez com bolinhas de gude...", em que se discute o sujeito negro e os movimentos de barganha que se impóem para que ele adentre o universo branco. Estes debates serâo desenvolvidos a seguir.

\section{1 “TODOS OLHARAM FEIO E DESPREZARAM EDUARDO POR ELE SER NEGRO"}

O livro infantil escolhido, caso năo tivesse um texto explicativo, permitiria diferentes interpretaçôes acerca do conflito principal. Uma possível interpretaçăo seria pensar que a história se trata das tentativas nada exitosas do menino Eduardo de se aproximar das demais crianças. O leitor também poderia se permitir elaborar outras justificativas, a fim de compreender as ocorrências de rejeiçăo. Talvez, o fato se desse, simplesmente, por Eduardo ser uma nova criança naquele contexto, e o grupo já existente ser fechado em si. A negativa a Eduardo poderia acontecer por ele ser um menino grosseiro, com quem as demais crianças năo estivessem dispostas a lidar. Ele poderia, inclusive, ter sido rechaçado por sua condiçăo socioeconômica, por suas roupas ou pelos modos de se portar. Entretanto, a descriçăo textual é incisiva: "Todos olharam feio e desprezaram Eduardo por ele ser negro" (REZENDE, 2012, p. 7).

Nessa direçấo, cabe o questionamento acerca do que motivaria crianças a desprezarem um outro tăo somente por este possuir uma cor de pele diferente da sua. É preciso que se analise, entâo, os valores arraigados na negativa a uma cor de pele que náo apenas é diferente: é negra! Trata-se de uma cor que tem uma história, que foi socialmente construída, tecida a partir do menosprezo do colono português aos negros e às negras, com a justificativa de uma suposta noçăo de racialidade que impôe a negros(as) um lugar biologicamente definido de inferioridade (QUIJANO, 2005).

Conforme o autor supracitado, essa classificaçăo racial é construída como estratégia para esclarecer e determinar a dominaçấo. Nas palavras de Quijano (2005, p. 118): "na América, a ideia de raça foi uma maneira de outorgar legitimidade às relaçóes 
de dominaçăo impostas pela conquista". Àquela época, o domínio era associado aos portugueses, ou seja, sujeitos europeus brancos. Cinco séculos depois, persistem pensamentos e atos que legitimam e naturalizam, entre brancos e negros, relaçôes de diferenciaçăo e de hierarquia, em que os sujeitos sâo qualificados e determinados pela cor da pele.

Nesse resgate histórico, localiza-se uma esfera de dominaçăo instaurada em 1500. Desde essa época, a noçăo de raça foi constituída e converteu-se no primeiro critério fundamental para a distribuiçâo da populaçâo mundial em níveis, lugares e papéis na estrutura de poder da nova sociedade. Por isso, na contramáo do mito da democracia racial, experimentamos, ainda hoje, resquícios coloniais que contribuem para a manutençăo de diferenciaçōes e classificaçóes que concedem aos brancos um lugar de privilégio, dentre os quais está a chamada branquitude. Acerca disso, Schucman (2012, p. 23) explicita:

\begin{abstract}
[...] a branquitude é entendida como uma posiçáo em que sujeitos que ocupam esta posiçăo foram sistematicamente privilegiados no que diz respeito ao acesso a recursos materiais e simbólicos, gerados inicialmente pelo colonialismo e pelo imperialismo, e que se mantêm e săo preservados na contemporaneidade. Portanto, para se entender a branquitude é importante entender de que forma se constroem as estruturas de poder concretas em que as desigualdades raciais se ancoram. Por isso, é necessário entender as formas de poder da branquitude, onde ela realmente produz efeitos e materialidades.
\end{abstract}

Em razâo disso, para a análise aqui proposta, recorremos, também, à historicidade. 0 Brasil é um país afrodiaspórico e tem, na sua história, o legado da escravidāo, ocupando a posiçăo de último país a abolir a escravizaçăo - apenas no ano de 1888. Diante disso, as relaçóes que se constituem hoje, social e politicamente, trazem as marcas das práticas coloniais e escravocratas, com o consequente processo de hierarquizaçăo racial e o silenciamento - ou negaçăo explícita - dos sujeitos brancos sobre toda essa analítica social.

Alguns dos efeitos dessa hierarquizaçăo racial săo, justamente, as desigualdades sociais e os movimentos e açôes racistas a que assistimos todos os dias, com uma classificaçăo de pessoas em boas ou más, pertinentes ou impertinentes, adequadas ou inadequadas, desejadas ou indesejadas, educadas ou năo educadas, tăo somente com base em sua expressăo fenotípica e na bagagem ancestral (e reprodutiva de modos de se relacionar) que traz consigo.

Voltando-nos à relaçâo do personagem Eduardo com as demais crianças do bairro, de quem tenta se aproximar, percebemos um movimento automático de exclusăo do menino negro. É provável que nâo haja uma reflexâo formal das crianças excludentes diante da açăo explícita que protagonizam, definida por uma noçáo de "aqui, criança negra náo entra". É possível, inclusive, que năo tenham sido ensinadas por seus pais, de uma maneira didática e elucidativa, sobre a distinçâo de seus lugares (melhores, superiores) em relaçâo aos lugares ocupados por negros. Ocorre, porém, que crianças săo subjetivadas a todo tempo nas relaçôes que estabelecem em seu cotidiano: sâo posicionadas, posicionam-se e posicionam outros sujeitos a partir de sentidos socialmente construídos que atribuem a si e ao outro. É assim que seguem movimentos regularizadores e reprodutores e já tensionam e reconstroem sentidos e modos de operar cotidianamente.

Ora, teçamos as seguintes consideraçôes: 1) na casa em que as crianças brancas vivem, os laços estreitados só existem com pessoas brancas (ou com a empregada/ 
babá negra, que tem um lugar demarcado pela funçăo que exerce, mediante a qual se subentende ou se explicita: "aproxime-se, mas năo muito!"); 2) em suas escolas, esta sistemática se reproduz (cumprimente os porteiros, cozinheiras, profissionais dos serviços gerais, sujeitos negros, "seja educado!" ou "olha! Até que aquele professor negro é bom"); 3) naquele bairro, até determinado momento, todas as demais crianças com quem conviveram săo brancas (e aquelas negras que por ali passam sequer sâo percebidas ou sâo olhadas com estranhamento, afinal "elas nâo săo como nós, nâo pertencem a este lugar"). Se em todos esses espaços expostos - nas instituiçóes familiar, escolar e comunitária -, salvo raras exceçōes, a presença discreta do negro se dá (se existir) em lugares subalternos e distantes, como, afinal, essas crianças poderăo entender o menino negro Eduardo como um de seus pares e, assim, năo o excluir? Percebemos, nessas inquietaçóes provocadas a partir da narrativa analisada, a potencialidade da literatura como prática discursiva que produz sentidos. $O$ caminho narrativo escolhido pelo autor está em nítida interaçáo com o cenário nacional em que se insere: a prerrogativa do preconceito racial está imersa em nossa cultura.

É preciso, pois, iluminar o debate sobre como lógicas discriminatórias se constroem cotidiana e sorrateiramente - o chamado racismo à brasileira, como apontam Schucman e Martins (2017) -, sendo reproduzidas isentas de reflexáo, uma vez que nâo interessa aos brancos interrogar uma situaçâo que lhes é confortável. É mais fácil projetar no outro, o negro, as marcas da invisibilidade, da indiferença e da violência explícita, lançando sobre ele aquilo que é rechaçado em si e em seus pares brancos. Nâo é à toa a construçăo discursiva, socialmente partilhada e reproduzida como ditado popular, que diz "a coisa tá preta" para sugerir que as situaçóes estăo estranhas, difíceis, ruins, fora do controle. Aqui também a cor preta tem conotaçâo pejorativa.

Nesse sentido, evidenciamos um problema racial que é estrutural e que expóe a formaçăo da naçăo brasileira em sua constituiçăo colonial e capitalista, a qual se funda a partir do trabalho escravo, expandindo-se e perpetuando-se pela exploraçáo, pelo trabalho precarizado e pela acumulaçăo de riquezas. Evidencia-se, assim, o papel das esferas política e econômica na determinaçăo de sujeitos, de práticas e de sentidos cotidianos, os quais sâo atravessados pela racialidade. Trazemos à tona, aqui, a reflexâo de Frankenberg (2004, p. 77) sobre a branquitude como

um lugar estrutural de onde o sujeito branco vê os outros e a si mesmo; uma posiçăo de poder náo nomeada, vivenciada em uma geografia social de raça como um lugar confortável e do qual se pode atribuir ao outro aquilo que năo atribui a si mesmo.

Torna-se, nesse âmbito, inevitável refletir sobre a branquitude - lugar de conforto e manutençăo de privilégios de brancos - para pensarmos e nos movimentarmos no sentido da desconstruçăo de práticas racistas vivenciadas no Brasil. Compreendemos e assumimos, em nossas reflexóes, que o racismo só acontece porque há uma lógica de branquitude que rechaça e reprime expressôes de negritude ou, simplesmente, a presença de negros em determinados contextos. A partir disso, explica-se por que o movimento denominado Black Lives Matter ${ }^{5}$ foi zombeteado por sujeitos brancos, inclusive

5 Em traduçăo livre, "Vidas negras importam". Trata-se de um movimento protagonizado, desde 2013, pelo ativismo internacional afro-americano, com reverberaçóes em diversas outras naçóes, que atuam contra a violência direcionada às pessoas negras 
no Brasil (TAYLOR, 2018). Como resposta a este movimento mundial, a branquitude pronuncia a tăo presente, infundada e agressiva resposta "mimimi"6.

É assim que identificamos, na branquitude e no branqueamento, peças fundamentais da ideologia racial brasileira, que segue racista. A pressăo, tanto simbólica quanto estrutural, que recai sobre negras e negros brasileiros, exige um movimento de negaçâo de si, do seu corpo, dos seus hábitos, de suas vestimentas e dos seus artefatos culturais legítimos como uma espécie de condiçâo para ser aceito, para gozar de mobilidade social, para branquear-se, tal como reflete Carone (2014).

Năo temos dúvidas de que este movimento intencional de apagamento do negro configura-se como estratégia da branquitude. Porém, mais uma vez, a perversidade deste grupo se evidencia ao fazer crer que esta seria uma iniciativa do próprio negro que, insatisfeito com sua condiçáo, buscaria embranquecer-se. Năo aparece nessa discussáo, todavia, o que Fanon (2008, p. 86) destaca, alertando-nos que é preciso "sentir de dentro o desespero do homem de cor diante do branco". Tendo isso em vista, o embranquecimento se refere, para o negro, como soluçâo à necessidade de inclusáo. Ao discutir sobre o complexo de inferioridade na estrutura psíquica inconsciente do negro, Fanon (2008, p. 95) denuncia:

Se ele se encontra a tal ponto submerso pelo desejo de ser branco, é que vive em uma sociedade que torna possível seu complexo de inferioridade, em uma sociedade cuja consistência depende da manutençăo desse complexo, em uma sociedade que afirma a superioridade de uma raça.

Podemos, ainda, aprofundar o recorte narrativo da literatura analisada, que evidencia uma parte da vida do personagem Eduardo, na infância, no contexto de adaptaçăo à mudança de bairro, e pensar: a partir dessa e de tantas experiências racistas que se acumularâo, como se constitui a identidade do negro brasileiro? Ele sentir-se-á à vontade para se afirmar um sujeito negro? Segundo Martino (2016, p. 146),

[...] a definiçăo de uma identidade está relacionada às possibilidades de exercêla como tal em público, em um processo de conquista muito mais do que outorga, do direito de ser quem se é e como se é. Ao mesmo tempo, a construçăo de uma identidade está ligada também ao espaço das representaçôes dessa identidade da maneira como ela é socialmente compreendida e situada nas várias hierarquias constituintes do espaço público. Dessa maneira, ser alguém é um ato político.

Prandini e Passos (2019, p. 71) ressaltam, ainda nessa perspectiva:

[...] Ser branco, ou seja, ocupar o lugar simbólico e se valer da branquitude, năo é algo estabelecido por questóes apenas genéticas, mas, sobretudo por posiçóes e lugares sociais que os/as sujeitos/as ocupam.

Em vista do que foi exposto, acrescentaríamos às consideraçôes das autoras: sentidos, posiçóes sociais e jogos de interesse envolvidos. Olhar para o sofrimento

6 Termo pejorativo utilizado para se referir a queixas supostamente vazias e desnecessárias. É proferido por sujeitos que náo se afetam pelo conteúdo em questăo. Podemos citar, como exemplo, sujeitos brancos que, com o desejo de afirmar que nâo existe racismo no Brasil, declaram: "o racismo é um mimimi". 
psíquico de Eduardo é, pois, favorecer a visibilidade do tema da racialidade e suas repercussóes. Se brancos assumem posicionamentos de brancos desde a tenra idade, com crianças que se sentem hierarquicamente superiores e autorizadas ao alheamento e a outras violências diante do negro, também, já muito cedo, crianças negras săo subjetivadas a acreditarem que săo inferiores e a desejarem ser năo negras.

Brancos se afirmam em sua identidade, enquanto negros e indígenas seguem sendo "os outros". Para se sentir inseridos, esses últimos cedem e vestem máscaras brancas para esconder suas peles negras (FANON, 2008). Para gozar da própria existência, para se sentir inserido, já no universo infantil, a barganha é um recurso utilizado. Por esse caminho, seguiu o nosso personagem Eduardo.

\section{2 “TENTOU NOVAMENTE SE APROXIMAR, DESSA VEZ COM BOLINHAS DE GUDE..."}

O trecho "Tentou novamente se aproximar, dessa vez com bolinhas de gude..." (REZENDE, 2012, p. 9) mostra-se como um atiçamento reflexivo e remete a uma experiência real, vivida no cotidiano de uma escola. Uma das autoras teve acesso a um relato sobre um garoto que, de forma semelhante à de Eduardo (personagem do livro), no desejo de se integrar a um grupo de crianças, "ofereceu" seu próprio corpo para ser usado sexualmente por outras crianças em troca de bolinhas de gude. Esta é mesmo uma história real. Nessa história, ficçâo e realidade se misturam como um modo de pôr em evidência a questăo da "inclusăo precária, instável e marginal" (MARTINS, 1997, p. 26), em que muitas crianças negras se encontram e que constitui as relaçóes étnico-raciais entre brancos e náo brancos. O autor, assim, nos leva ao encontro de um problema social: como se dá a inclusâo numa sociedade em que a exclusâo é tomada como modo de vida? Sua instigaçăo continua:

\footnotetext{
[...] rigorosamente falando, năo existe exclusăo; existe contradiçăo, existem vítimas de processos sociais e políticos e econômicos excludentes; existe o conflito pelo qual a vítima dos processos excludentes proclama seu inconformismo, seu mal-estar, sua revolta, sua esperança, sua força reivindicativa e sua reivindicaçăo corrosiva. Essas reaçōes, porque năo se trata estritamente de exclusăo, năo se dăo fora dos sistemas econômicos e dos sistemas de poder. Elas constituem o imponderável de tais sistemas. (MARTINS, 1997, p. 14)
}

A partir da citaçâo acima e das discussôes feitas até aqui, é possível afirmar que do modo como a sociedade se organiza, com suas práticas, rituais, discursividades, aparelhos repressores e base econômica excludentes, năo acontece, de fato, uma inclusăo. 0 menino negro, Eduardo, é envolvido e cercado por questōes sociais que o colocam numa situaçăo periférica que lhe é estranha. É um estar perto e, ao mesmo tempo, longe, desvelando a contradiçấo de uma "inclusăo social precária, instável, marginal", como citado acima. Nessa linha de pensamento, podemos pontuar que

[...] exclusăo de fato náo existe. Ela é, na sociedade moderna, apenas um momento da dinâmica de um processo mais amplo: um momento insuficiente para compreender e explicar todos os problemas que a exclusáo efetivamente produz na sociedade atual". (MARTINS, 1997, p. 26) 
Neste tópico, buscamos discutir, entâo, sobre a criança negra e como ela se impóe movimentos de barganha, muitas vezes de forma violenta, para adentrar o universo branco, no qual esses movimentos sáo vistos apenas de forma unilateral, negando ou invisibilizando o lugar da branquitude no processo de racializaçăo. Torna-se importante dizer que, etimologicamente, a palavra "barganha" tem sua origem no idioma francês, barbaignier, que significa "discutir o preço, regatear", bem como no frâncico, borganjan, "emprestar" (ORIGEM DA PALAVRA, 2021).

Ambas as possibilidades de origem demarcam o enraizamento da atitude de barganhar no movimento de desigualdade das relaçóes e, aqui especificamente, nas relaçóes entre crianças brancas e negras, em que a branquitude segue sendo lida como poder e tendo privilégios simbólicos e materiais. É um fenômeno que colabora com a questăo da iniquidade, da discriminaçâo e dos preconceitos raciais. Para Cardoso (2010b, p. 81), a branquitude é, pois, "um lugar estrutural de onde o sujeito branco vê os outros e a si mesmo, uma posiçăo de poder, um lugar confortável no qual se pode atribuir ao outro aquilo que năo se atribui a si mesmo". Essa branquitude acrítica sustenta-se em atitudes que trazem benefícios para uma superioridade racial branca. No entanto, vale ressaltar que ela se constrói e se reconstrói histórica, social e culturalmente, modificando-se no decorrer do tempo.

Pensar nesse sentido originário pode ser um caminho para, de um lado, ver-se o quanto ainda está sendo demarcado, mesmo em países latino-americanos, um modo de existir assentado em um modelo eurocêntrico, colonizador, branqueador, segregador; e para, de outro, promover uma denúncia em direçâo a se libertar de um pensamento subalterno. Para tanto, pensa-se na possibilidade de se encontrar uma criança que se apropriou de questóes como gênero, raça/cor, classe, por meio das quais ela pode ser diferenciada, e năo universalizada, de um olhar hegemônico europeu ou norte-americano. Como aponta Dourado (2020, p. 255),

[...] uma resistência que hoje aparece nos debates pós-coloniais e decoloniais, nos quais o colonizado de tradiçóes mistas, (para năo usar mestiço, pois abre questôes epistemológicas que năo cabem aqui) busca uma imagem para se espelhar. Seria talvez uma resistência subjetiva de questionamento da sua alteridade ou reivindicaçấo da sua subjetividade, em que nâo é mais possível acreditar que o modelo de homem ocidental europeu é espelho de povos de múltiplas etnias, culturas, territórios.

Eis uma luta constante de uma criança negra, no caso aqui analisado, de um menino negro. Como se espelhar num modelo eurocêntrico no qual năo se reconhece? Como ser reconhecido como um outro, mas nâo um outro desqualificado? Como construir relaçóes em que a alteridade seja uma via de convivência respeitosa? Diante dessas provocaçóes, fica-se a refletir acerca do grau de prestígio que um grupo de crianças brancas detém para ignorar um menino negro, um novo vizinho. Ou seja, é a presença marcante e destrutiva da supremacia branca.

A atribuiçăo de valor às diferenças fenotípicas e étnico-raciais apresentada pelo grupo de meninos brancos contribui para a formaçăo de atitudes etnocêntricas e hierárquicas. Podemos, assim, apontar que o título do livro já anuncia, de forma discriminatória, a marca do fenótipo da textura do cabelo de Eduardo, "Cabelo de Mola", desvelando a presença do preconceito na obra analisada. 
Confrontando-nos com esse título, é possível perceber o quanto o racismo está imbricado na organizaçáo da sociedade e, conforme afirma Ribeiro (2019, p. 38), "é impossível nâo ser racista sendo criado numa sociedade racista. É algo que está em nós e contra o que devemos lutar sempre". Isto é, mesmo que o autor tenha desejado escrever um livro para discutir racismo, a linguagem utilizada expressa um atravessamento pelas marcas culturais do racismo. Como assinala a referida autora, importa compreender que "a linguagem também é carregada de valores sociais, e que por isso é preciso utilizá-la de maneira crítica deixando de lado expressōes racistas" (RIBEIRO, 2019, p. 39) - como no caso do uso do termo "cabelo de mola" para se referir ao cabelo de um negro.

Caminhando pela leitura do livro em questăo, encontra-se: “Um dia após a mudança, Eduardo foi correndo para a rua conhecer os meninos da vizinhança. Aconteceu, porém, algo lamentável! Todos olharam feio e desprezaram Eduardo por ele ser negro" (REZENDE, 2012, p. 7). O autor reduz a rejeiçấo por parte dos meninos brancos da vizinhança a um único fator: a negritude. Pode-se perguntar: o que o teria levado a restringir o desprezo das crianças à cor da pele? Compreendendo a linguagem como prática social contextualizada, corroboramos a visăo de Spink e Medrado (2013), para quem as práticas discursivas podem ser vistas como linguagem ativa, ou seja, mostram-se como modos/atitudes diante das interaçóes sociais cotidianas, sendo, entâo, produtoras de sentidos.

À vista disso, a questâo da raça/cor se evidencia na narrativa como expressividade da linguagem social excludente. Chama, também, a atençâo o fato de Eduardo ser um "novo vizinho", expressăo que remete à proximidade, à familiaridade, a estar junto, ao mesmo tempo que se refere a desconhecimento, à estranheza, aspectos estes nâo considerados pelo autor como possível explicaçấo do desprezo das crianças brancas. No entanto, a ênfase na discriminaçấo étnico-racial alimentada pela branquitude transforma a criança negra em "algo" a ser distanciado, ignorado, extirpado, enquanto "o ser branco é considerado como padrăo normativo único" (CARDOSO, 2010a, p. 611).

Assim, fica revelada, nas práticas discursivas do livro em análise, a presença cotidiana do racismo, uma vez que a marca de distinçâo entre os meninos se dá em funçâo da raça, disseminando as desigualdades sociais. Entâo, a escrita da obra expressa uma discursividade racista que constitui o próprio escritor. Nesse sentido, as práticas discursivas racistas escapam nas "vozes escritas".

O olhar estrangeiro se impóe pelo inverso: um povo múltiplo por sua origem, sua etnia e sua cultura se movimenta buscando ou desejando relaçôes com um único povo branco, alimentando o pensamento colonizador. E o que fica para Eduardo? Tentar barganhar com suas bolinhas de gude um lugar de pertença ao grupo parece a única saída possível nesse contexto discriminatório. Ao negar a presença da diferença, bem como a tentativa de criar um arsenal hegemônico que prioriza o ser branco, o preconceito se mostra como uma tentativa de cristalizar e fixar modos de ser distintos em um padrâo que nega a equidade entre humanos. Aceitar as diferenças pressupóe atribuir aos sujeitos igualdade de direitos e de oportunidades. $\mathrm{O}$ respeito às diferenças implica uma reciprocidade em relaçōes igualitárias.

Surge, entăo, na história, a presença do inusitado, do inesperado, tăo próprio do existir humano. Rezende (2012, p. 17) narra: "algo inesperado aconteceu. Um dos 
meninos chamou Eduardo para completar seu time de futebol, e ele, muito feliz, aceitou o convite". Esse acontecimento ilustra como o conviver está atravessado

[...] pela mobilidade, pela errância, pelo imprevisível... como também, pela abertura de ser atravessadas pelo inusitado, pelo outro, num encontro onde nada é pré-determinado, pré-concebido, estando dis-postas ao espanto, ao estranho, ao inesperado, que se manifestam na existência cotidiana. (SANTOS, 2016, p. 187-188)

Eduardo experienciou a inospitalidade do mundo unicamente por ser uma criança negra. Entretanto, a experiência humana tem a fluidez, o imprevisível, o indeterminado como condiçăo própria do existir. Num entrelaçamento com o inesperado, fazse necessário assinalar a atitude de luta de Eduardo, mesmo envolto em sofrimento: "Eduardo, de longe, observava os meninos brincarem" (REZENDE, 2012, p. 16). Ele năo arredou o pé, ele se pôs à vista, ele resistiu. Esse olhar năo é romântico. Esse olhar é uma denúncia de que a luta para ser visto/reconhecido é diária e está presente na experiência cotidiana do povo negro.

\section{CONSIDERAÇÕES FINAIS}

Em tempos nos quais o racismo avança a passos largos no Brasil e no mundo, faz-se essencial pôr em questăo a nociva persistência de um pensamento binário que opóe o ser branco ao ser negro. Conviver com a disseminaçăo de verdades tomadas como absolutas e que povoam o imaginário da humanidade favorece o projeto excludente de uma sociedade apoiada na crença de uma história única e universal.

Realizar um discurso racial focado unicamente no negro legitima as desigualdades raciais, negando o papel do branco nesse processo e alimentando a atitude do universo branco de desprezar, exclusivamente pela cor, a participaçăo do negro no cotidiano das relaçóes sociais. Essa realidade traz, em seu bojo, a marca do processo de colonizaçâo por meio da ideia de inferioridade, por natureza, do negro e nutre o pensamento de que diferença e desigualdade săo sinônimas.

Essas relaçōes de diferenciaçōes, hierarquizaçôes pela cor, ameaçam direitos e conquistas sociais e sustentam açōes e movimentos racistas. Como visto na história de Eduardo, năo săo poucos os desafios para descolonizar pensamentos que historicamente relegam a participaçâo da populaçăo negra, desde brincadeiras de crianças até um alto posto no trabalho. O grito "vidas negras importam" é um eco diário que denuncia a contradiçăo presente numa sociedade que invisibiliza e encobre a presença do negro, estampando suas atitudes discriminatórias, excludentes, preconceituosas.

O livro escolhido para tecer essas reflexôes reforça uma prática discursiva excludente já no seu título, "Cabelo de Mola", e em sua trajetória, que demarca um caminho de barganha trilhado por um menino negro para ser visto e reconhecido, tendo que, ao final, provar que é muito bom no jogo de futebol. É um caminho de luta cotidiana, é sair todo dia tendo que provar ao outro que é bom. Ou seja, năo há aceitaçăo, reconhecimento por ser criança. Sendo uma criança negra, tem que provar que faz o gol mais bonito.

Quais corpos merecem ser aceitos? Afinal, quais corpos têm cor? Menino de cor! O que essa expressấo representa para a populaçấo negra? O menino de cor é negro, mas o branco, que tenta se encobrir como sendo sem cor, predomina e prevalece, e a 
discriminaçăo étnico-racial alimentada pela branquitude segue encorajando as desigualdades sociais que, já na infância, săo fincadas no pensamento colonizador.

Menino negro, criança, cabelo de mola: aqui você năo entra! Por que aqui você năo entra? Questionar, agir, intervir e transformar săo açôes a que somos convocados e que, aqui, convocamos. E urgente descolonizar desde a infância! 


\section{REFERÊNCIAS}

AMARAL, A. C. T. A infância pequena e a construçăo da identidade étnico-racial na Educaçâo Infantil. 2013. 225 f. Tese (Doutorado em Educaçăo) - Setor de Educaçấo, Universidade Federal do Paraná, Curitiba, 2013.

ARROYO, M. G. Outros Sujeitos, outras pedagogias. Petrópolis: Vozes, 2012.

BENTO, M. A. S. Branqueamento e branquitude no Brasil. In: CARONE, I.; BENTO, M. A. S. (org.). Psicologia social do racismo: estudos de branquitude e branqueamento no Brasil. Petrópolis, Rio de Janeiro, 2014, p. 25-58.

BRASIL. Casa Civil. Lei n 10.639, de 9 de janeiro de 2003. Altera a Lei no 9.394, de 20 de dezembro de 1996, que estabelece as diretrizes e bases da educaçấo nacional, para incluir no currículo oficial da Rede de Ensino a obrigatoriedade da temática História e Cultura Afro-Brasileira, e dá outras providências. Brasília, DF: Presidência da República, 2003. Disponível em: 〈https://www.planalto.gov. br/ccivil_03/leis/2003/110.639.htm〉. Acesso em: 26 jun. 2021.

BRASIL. Casa Civil. Lei ${ }^{\circ}$ 11.645, de 10 de março de 2008. Altera a Lei no 9.394, de 20 de dezembro de 1996, modificada pela Lei no 10.639, de 9 de janeiro de 2003, que estabelece as diretrizes e bases da educaçăo nacional, para incluir no currículo oficial da rede de ensino a obrigatoriedade da temática "História e Cultura Afro-Brasileira e Indígena". Brasília, DF: Presidência da República, 2008. Disponível em: <http://www. planalto.gov.br/ ccivil_03/_Ato2007-2010/2008/Lei/L11645.htm>. Acesso em: 26 jun. 2021.

BRASIL. Ministério da Educaçăo. Diretrizes curriculares nacionais para a educaçăo das relaçóes étnico-raciais e para o ensino de história e cultura afro-brasileira e africana. Brasília: MEC, 2004.

CANDIDO, A. O direito à literatura. In: Vários escritos. 5. ed. Rio de Janeiro: Ouro sobre azul, 2011, p. 171-193.

CARDOSO, L. Branquitude acrítica e crítica: A supremacia racial e o branco anti-racista. Revista latinoamericana de ciencias sociale, niñez y juventud, v. 8, n. 1, p. 607-630, 2010a. Disponível em: <http://biblioteca.clacso.edu.ar/Colombia/alianza-cinde-umz/20131216065611/art.LourencoCardoso.pdf>. Acesso em: 18 abr. 2021.

. Retrato do branco racista e anti-racista. Reflexăo e açăo, v. 18, n. 1, p. 46-76, 2010b. Disponível em: <http://online.unisc.br/seer/index.php/reflex/article/viewFile/1279/1055>. Acesso em: 20 nov. 2015.

CARONE, I. Breve histórico de uma pesquisa psicossocial sobre a questăo racial brasileira. In:___ _BENTO, M.A. S. (org.). Psicologia social do racismo: estudos sobre branquitude e branqueamento no Brasil. Rio de Janeiro: Editora Vozes, 2014, p. 13-24.

DOURADO, M. P. B. Na América decolonial: crianças ou infâncias? Uma interrogaçáo sobre a teorizaçáo da fase inicial da vida. Revista de Ciências Sociais, Fortaleza, v. 50, n. 3, p. 249-266, nov. 2019/fev. 2020. Disponível em: <http://repositorio.ufc.br/bitstream/ riufc/49879/1/2020_art_mpbdourado.pdf>. Acesso em: 18 abr. 2021. 
FANON, F. Pele negra, máscaras brancas. Traduçăo de Renato da Silveira. Salvador: EDUFBA, 2008.

FRANKENBERG, R. A miragem de uma branquidade năo-marcada. In: WARE, V. (org.). Branquidade: identidade branca e multiculturalismo. Rio de Janeiro: Garamond, 2004.

HOOKS, B. Ensinando pensamento crítico: sabedoria prática. Traduçăo de Bhuvi Libanio. Săo Paulo: Elefante, 2020.

.We real cool: black man and masculinity. New York: Routledge, 2004.

MARTINO, L. Midiatizaçáo da religiâo e Estudos Culturais: uma leitura de Stuart Hall. MATRIZes, v. 10, n. 3, p. 143-156, 2016. Disponível em: <https://www.revistas.usp.br/ matrizes/article/view/124655>. Acesso em: 21 abr. 2021.

MARTINS, J. S. Exclusāo social e a nova desigualdade. Săo Paulo: Paulus, 1997.

MENDONÇA, É. de S. Práticas discursivas sobre participaçăo política juvenil: entre os prazeres, orgulho e sacrifícios. 2008. 140 f. Dissertaçăo (Mestrado em Psicologia) Universidade Federal de Pernambuco (UFPE), Recife, 2008.

ORIGEM DA PALAVRA. Palavra Barganha. Disponível em: <https://origemdapalavra.com.br/palavras/barganha/\#:-text=Ela\%20vem \%20do\%20 antigo\% 20 Franc\%C 3\%AAs,Fr\%C3\%A2ncico\% 20 BORGANJAN\% 2 C \% 20 \%E2\%80\%9Cemprestar\%E2\%80\%9D>. Acesso em: 18 abr. 2021.

PIZA, E.; ROSEMBERG, F. Cor nos censos brasileiros. In: CARONE, I. (org.). Psicologia social do racismo: estudos sobre branquitude e branqueamento no Brasil. Petrópolis: Vozes, 2014, p. 91-120.

PRANDINI, P.; PASSOS, A. H. Branquitude no Brasil: desafios para uma educaçăo decolonial na sociedade pós-colonial. Trama Interdisciplinar, v. 10, n. 2, p. 63-79, 2019.

QUIJANO, A. Colonialidade do poder, eurocentrismo e América Latina. Buenos Aires: CLACSO, 2005.

REZENDE, A. Cabelo de Mola. Sáo Paulo: Paulos Editora, 2012.

RIBEIRO, D. Pequeno Manual Antirracista. Sâo Paulo: Companhia das Letras, 2019.

SANTOS, S. E. de B. "Olha!... Arru(a)çăo!?..." - A açăo clínica no viver cotidiano: conversaçâo com a fenomenologia existencial. 2016. 221 p. Tese (Doutorado em Psicologia Clínica) - Universidade Católica de Pernambuco, Recife, 2016

SCHUCMAN, L. V. Entre o “encardido", o "branco" e o “branquíssimo”: Raça, hierarquia e poder na construçấo da branquitude paulistana. 2021. 122 p. Tese (Doutorado em Psicologia) - Universidade de Sáo Paulo, Săo Paulo, 2012.

. MARTINS, H. V. A Psicologia e o Discurso Racial sobre o Negro: do "Objeto da Ciência" ao Sujeito Político. Psicologia: Ciência e Profissáo, v. 37, n. esp., p. 172-185, 2017. Disponível em: 〈https://doi.org/10.1590/1982-3703130002017〉. Acesso em: 14 abr. 2021.

SILVA, T. R. da. Criança e negra: o direito à afirmaçâo da identidade negra na Educaçăo Infantil. 2015. 223 f. Tese (Doutorado em Educaçấo) -, Universidade Federal da Paraíba (UFPB), Joăo Pessoa, 2015. 
SOUZA, F. M. Revirando malas: entre histórias de bonecas e de crianças. 2009. 134 f. Dissertaçăo (Mestrado em Educaçăo) - Faculdade de Educaçăo, Universidade Federal do Rio Grande do Sul, Porto Alegre, 2009.

SPINK, M. J. Linguagem e produçăo de sentidos no cotidiano. Porto Alegre: EDIPUCRS, 2010.

; MEDRADO, B. Produçăo de sentidos no cotidiano: uma abordagem teórico-metodológica para análise das práticas discursivas. In: SPINK, M. J. (org.). Práticas discursivas e produçáo de sentidos no cotidiano: aproximaçôes teóricas e metodológicas. Săo Paulo: Cortez, 2013, p. 21-41.

TAYLOR, K-Y. O surgimento do movimento \#blacklivesmatter [vidas negras importam]. Lutas Sociais, v. 22, n. 40, p. 108-123, 2018. Disponível em: <https://revistas.pucsp.br/ ls/article/view/46658?fbclid=IwAR28yG6ruqT8JEGARHrgLx4YeUccBpN93lEONFqc6B7YhYbgD0rNUlWxPZs>. Acesso em: 21 abr. 2021.

TRINIDAD, C. T. Identificaçăo étnico-racial na voz de crianças em espaços de Educaçăo Infantil. 2011. 221 f. Tese (Doutorado em Educaçăo) - Programa de Pós-Graduaçăo em Educaçăo, Pontifícia Universidade Católica de Săo Paulo, Săo Paulo, 2011. 